\title{
DISTRIBUSI LOGAM BERAT CU PADA AIR LAUT PERMUKAAN DI PERAIRAN TELUK STARING SULAWESI TENGGARA
}

\section{Distribution of Heavy Metal Cu in Seawater Surface of Staring Bay South East Sulawesi}

\author{
Arjuna $^{1}$, Alrum Armid ${ }^{2}$, dan Amadhan Takwir ${ }^{3}$ \\ ${ }^{1}$ Mahasiswa Jurusan Ilmu Kelautan, \\ Fakultas Perikanan dan Ilmu Kelautan, Universitas Halu Oleo. \\ Jl. H.E.A Mokodompit Kampus Hijau Bumi Tridharma Anduonohu Kendari 93232, Telp/Fax: (0401) 3193782 \\ ${ }^{2}$ Surel: armid@uho.ac.id \\ ${ }^{3}$ Surel: awhier@gmail.com
}

\begin{abstract}
Abstrak
Kandungan logam berat di suatu perairan sangat berbahaya apabila telah melewati standar baku mutu. Salah satu logam berat yang termasuk bahan beracun dan berbahaya adalah logam berat $\mathrm{Cu}$. Logam berat $\mathrm{Cu}$ masuk ke dalam lingkungan perairan akibat factor antropogenik seperti buangan limbah industri, pelayaran, pertanian dan buangan limbah rumah tangga. Penelitian ini bertujuan untuk mengidentifikasi distribusi spasial dan status pencemaran logam berat $\mathrm{Cu}$ di Perairan Teluk Staring. Pengambilan sampel air laut permukaan sebanyak 12 stasiun dilakukan dengan metode Purposive Random Sampling. Larutan sampel dianalisis dengan Spektrofotometri Serapan Atom (SSA) sedangkan sebaran spasial dianalisis melalui metode interpolasi Inverse Distance Weight (IDW). Hasil pengukuran menunjukkan bahwa nilai kadar Logam Cu di 12 Stasiun sebesar 0,0025-0,1147 ppm. Nilai rata-rata logam Cu adalah sebesar 0,055 ppm. Kadar logam $\mathrm{Cu}$ tertinggi terdapat pada Stasiun 7 dan 8. Hasil analisis spasial menunjukkan bahwa telah terjadi kontaminasi logam berat $\mathrm{Cu}$ di daerah pesisir Pulau Lara, Kec. Moramo Utara sampai pesisir Pulau Labotaone, Kec. Laonti dengan kisaran nilai kadar logam sebesar 0,0523-0,1147 ppm. Status pencemaran logam berat $\mathrm{Cu}$ pada area tersebut telah melewati nilai standar baku mutu sesuai KepMen LH, No. 51 Tahun 2004. Variabel lingkungan (Suhu, Salinitas dan pH) terhadap konsentrasi Logam Berat $\mathrm{Cu}$ tidak memiliki pengaruh yang signifikan terhadap sebaran kandungan logam berat $\mathrm{Cu}$.
\end{abstract}

Kata Kunci: Logam Berat Tembaga (Cu), Distribusi, Status Pencemaran, Teluk Staring

\begin{abstract}
Content of heavy metal in seawater is very dangerous when exceeded the quality standard. One of heavy metals that harmful toxic materials is $\mathrm{Cu}$. Input of heavy metal $\mathrm{Cu}$ to the marine environment is governed by antrophogenic activities, including industrial wastes as well as residues from shipping, agricultural and household activities. This study aims to identify the spatial distribution of $\mathrm{Cu}$ in the coastal waters of Staring Bay. Sampling was performed in 12 stations by the Purposive Random Sampling method and analyzed by Atomic Absorption Spectrophotometry (AAS). Spatial distribution was analyzed through Inverse Distance Weight (IDW) Interpolation method. The result shows that the concentration of $\mathrm{Cu}$ in 12 Station ranged from 0,0025 to $0,1147 \mathrm{ppm}$, with average of $0,055 \mathrm{ppm}$. The highest concentration of $\mathrm{Cu}$ was found at stations 7 and 8. The result of spatial analysis indicated that there had been contaminated by heavy metal $\mathrm{Cu}$ ranged from the coastal areas of Lara Isle, Sub-district of North Moramo to the Labotaone Isle, Sub-district of Laonti with the concentration of 0,0523-0,1147 ppm. Accordingly, those areas refer to the "polluted area" following the minister of Environment Decree No. 51 of 2004 . The present study confirms that temperature, salinity and $\mathrm{pH}$ of seawater have no significant effects to the distribution of heavy metal $\mathrm{Cu}$ in the study area.
\end{abstract}

Keywords: Heavy Metal Copper (Cu), Distribution, Pollutant Status, Staring Bay

\section{Pendahuluan}

Pencemaran air adalah masuknya atau dimasukkannya makhluk hidup dan komponen lain yang berasal dari alami atau aktivitas manusia ke dalam air sehingga tidak sesuai lagi dengan peruntunannya. Salah satu indikator yang digunakan untuk mendeteksi pencemaran air adalah adanya kandungan logam berat didalamnya. Disebut logam berat berbahaya karena umumnya memiliki rapat massa tinggi $\left(5 \mathrm{~g} / \mathrm{cm}^{3}\right)$ dan sejumlah konsentrasi kecil dapat bersifat racun dan berbahaya. Diantara semua unsur logam berat, $\mathrm{Hg}$ menduduki urutan pertama dalam hal sifat racunnya, kemudian diikuti oleh logam berat antara lain $\mathrm{Cd}, \mathrm{Ag}, \mathrm{Ni}, \mathrm{Pb}, \mathrm{As}, \mathrm{Cr}, \mathrm{Sn}$, dan $\mathrm{Zn}$. Logam berat merupakan komponen alami tanah. Logam berat masih termasuk golongan logam dengan kriteria-kriteria yang sama dengan logam-logam lainnya. Perbedaannya terletak dari pengaruh yang 
dihasilkan bila logam berat ini berikatan dan atau masuk ke dalam tubuh organisme hidup. Berdasarkan sudut pandang toksikologi, logam berat ini dapat dibagi dalam dua jenis. Jenis pertama adalah logam berat esensial, dimana keberadaannya dalam jumlah tertentu sangat dibutuhkan oleh organisme hidup, namun dalam jumlah yang berlebihan dapat menimbulkan efek racun. Contoh logam berat ini adalah $\mathrm{Zn}, \mathrm{Cu}, \mathrm{Fe}, \mathrm{Co}, \mathrm{Mn}$ dan lain sebagainya. Sedangkan jenis kedua adalah logam berat tidak esensial atau beracun, dimana keberadaannya dalam tubuh masih belum diketahui manfaatnya atau bahkan dapat bersifat racun, seperti $\mathrm{Hg}, \mathrm{Cd}, \mathrm{Pb}, \mathrm{Cr}$ dan lain-lain.

Tembaga bersumber dari peristiwa pengikisan (erosi) dari batuan mineral, debu, dan partikel-partikel $\mathrm{Cu}$ yang ada dalam lapisan udara yang di bawah turun oleh hujan (Laws, 1993). Cu masuk ke dalam lingkungan perairan akibat dari aktivitas manusia seperti buangan limbah industri yang mengandung $\mathrm{Cu}$, campuran bahan pengawet, industri pengelolaan kayu, buangan rumah tangga, dan sebagainya (Palar, 2004). Sebagai contoh, unsur logam Tembaga $(\mathrm{Cu})$, bila masuk ke dalam tubuh dalam jumlah berlebihan akan menimbulkan pengaruh-pengaruh buruk terhadap fungsi fisiologi tubuh.

Sumber pencemaran logam berat yang memungkinkan ada di Teluk Staring yaitu banyaknya pabrik-pabrik yang terdapat di sekitar daratan daerah Moramo sampai Moramo Utara seperti pabrik PLTU, pabrik semen, gas, dan perumahan, industri bahan kimia yang limbahnya akan langsung mengalir ke laut dengan banyaknya daerah aliran sungai di daerah tersebut. Selain itu, banyaknya lahan perkebunan masyarakat yang berpotensi adanya bahan-bahan kimia yang di pakai oleh petani. Di Teluk Staring ini juga banyak terdapat aktivitas kapal-kapal laut yang melintas, baik itu kapal ikan ataupun kapal masyarakat, sehingga kemungkinan dapat terjadi tertumpahnya minyak-minyak kapal ke laut yang dapat menyebabkan tercemarnya air laut.

Kandungan material berbahaya memiliki dampak yang bermacam-macam dalam perairan. Ada yang berdampak langsung maupun tidak langsung. Limbah kimia yang bersifat toxic (racun) yang masuk ke perairan laut akan menimbulkan efek yang sangat berbahaya. Kelompok limbah kimia ini terbagi dua, pertama kelompok racun yang sifatnya cenderung masuk terus menerus seperti pestisida, furan, dioksin dan fenol. Terdapat pula logam berat, suatu unsur kimia metalik yang memiliki kepadatan yang relatif tinggi dan bersifat racun atau beracun pada konsentrasi rendah. Contoh logam berat yang sering mencemari adalah air raksa, timah, nikel, arsenik dan cadmium. Ketika pestisida masuk ke dalam ekosistem laut, mereka segera diserap ke dalam jaring makanan di laut. Sehingga mengganggu organisme lain bahkan bisa mematikan.

Perairan Teluk Staring merupakan salah satu perairan di Sulawesi Tenggara yang terletak di Kecamatan Moramo Kabupaten Konawe Selatan. Perairan Teluk Staring ini dijadikan sebagai sumber mata pencaharian bagi sebagian besar masyarakat yang umumnya bekerja sebagai nelayan. Selain itu, perairan Teluk Staring juga dijadikan sebagai tujuan wisata bagi masyarakat lokal. Adanya aktifitas-aktifitas tersebut juga diduga akan menimbulkan dampak bagi kondisi ekosistem laut.

Penelitian ini dilakukan untuk menginvestigasi sejauh mana tingkat pencemaran Logam Tembaga $(\mathrm{Cu})$ melalui analisis spasial distribusi logam berat yang terjadi pada perairan di daerah Teluk Staring.

\section{Bahan dan Metode}

Penelitian dilaksanakan pada bulan Januari sampai dengan bulan Mei 2019 . Pengambilan sampel air dilakukan di perairan Teluk Staring termasuk ke dalam wilayah administrasi Kecamatan Laonti, Kecamatan Moramo, dan Kecamatan Moramo Utara Kabupaten Konawe Selatan, Provinsi Sulawesi Tenggara dengan posisi koordinat $4^{\circ} 02^{\prime} 40^{\prime \prime}$ $4^{\circ} 08^{\prime} 53^{\prime \prime}$ LS dan $122^{\circ} 40^{\prime} 03^{\prime \prime}-122^{\circ} 48^{\prime} 02^{\prime \prime}$ BT. Selain itu, Preparasi sampel dilakukan di Laboratorium Analitik Fakultas Matematika dan Ilmu Pengetahuan Alam, Universitas Halu Oleo, dan Analisis kadar logam berat dengan Spektrofotometer Serapan Atom (SSA) dilakukan di Laboratorium Ilmu Tanah Fakultas Pertanian, Universitas Halu Oleo.

Metode yang digunakan dalam menentukan lokasi sampling untuk pengambilan sampel air laut adalah purpossive sampling yang merupakan penentuan lokasi sampel yang sudah ditentukan pada stasiun pengamatan. Pengambilan sampel dilakukan pada 12 stasiun seperti yang pada Gambar 1. 


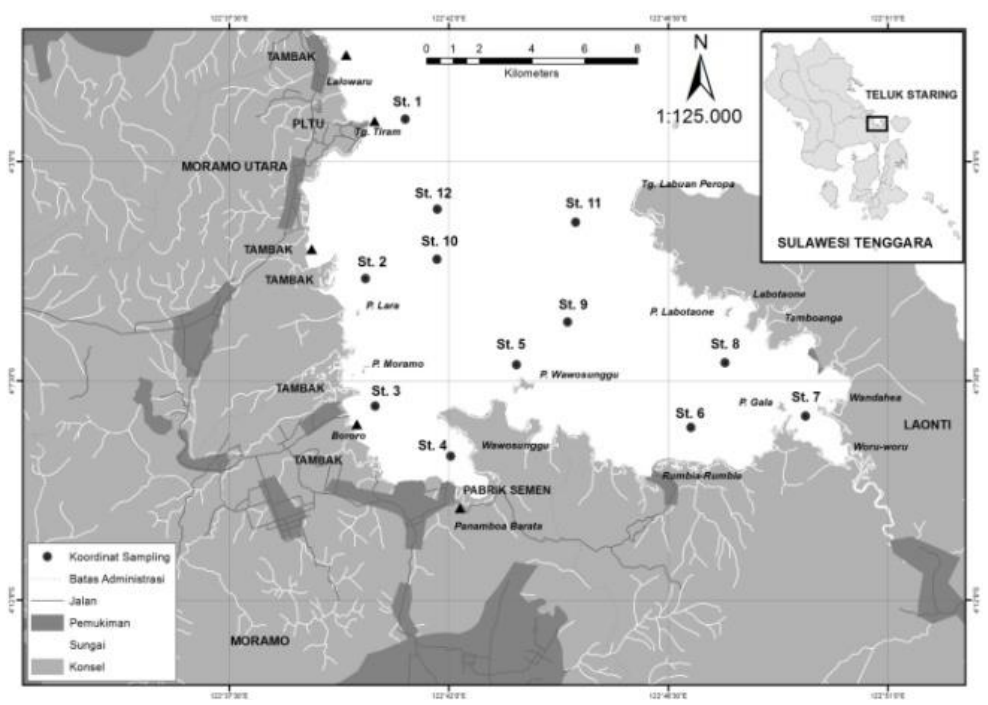

Gambar 1. Kawasan Perairan Teluk Staring memperlihatkan 12 stasiun pengambilan sampel.

Tabel 1. Titik koordinat 12 stasiun sampel

\begin{tabular}{cccl}
\hline \multirow{2}{*}{ Stasiun } & \multicolumn{2}{c}{ Koordinat } & \multicolumn{1}{c}{ Lokasi } \\
\cline { 2 - 3 } & BT & LS & \\
\hline 1 & $122^{\circ} 41^{\prime} 6.44^{\prime \prime}$ & $4^{\circ} 2^{\prime} 7.79^{\prime \prime}$ & Dermaga Tanjung Tiram \\
2 & $122^{\circ} 40^{\prime} 17.68^{\prime \prime}$ & $4^{\circ} 5^{\prime} 24.39^{\prime \prime}$ & Pulau Lara \\
3 & $122^{\circ} 40^{\prime} 29.26^{\prime \prime}$ & $4^{\circ} 8^{\prime} 0.95^{\prime \prime}$ & Teluk Moramo \\
4 & $122^{\circ} 42^{\prime} 2.19^{\prime \prime}$ & $4^{\circ} 9^{\prime} 2.77^{\prime \prime}$ & Teluk Moramo \\
5 & $122^{\circ} 43^{\prime} 23.20^{\prime \prime}$ & $4^{\circ} 7^{\prime} 10.34^{\prime \prime}$ & P.Wawosunggu \\
6 & $122^{\circ} 46^{\prime} 57.83^{\prime \prime}$ & $4^{\circ} 8^{\prime} 27.56^{\prime \prime}$ & Pesisir Rumbi-Rumbia \\
7 & $122^{\circ} 49^{\prime} 18.90^{\prime \prime}$ & $4^{\circ} 8^{\prime} 13.66^{\prime \prime}$ & Muara Sungai Laonti \\
8 & $122^{\circ} 47^{\prime} 39.56^{\prime \prime}$ & $4^{\circ} 7^{\prime} 7.75^{\prime \prime}$ & P. Labotaone \\
9 & $122^{\circ} 44^{\prime} 26.20^{\prime \prime}$ & $4^{\circ} 6^{\prime} 17.44^{\prime \prime}$ & P. Wawosunggu \\
10 & $122^{\circ} 41^{\prime} 45.48^{\prime \prime}$ & $4^{\circ} 5^{\prime} 0.16^{\prime \prime}$ & Laut Dalam \\
11 & $122^{\circ} 44^{\prime} 35.97^{\prime \prime}$ & $4^{\circ} 4^{\prime} 14.46^{\prime \prime}$ & Laut Dalam \\
12 & $122^{\circ} 41^{\prime} 45.70^{\prime \prime}$ & $4^{\circ} 3^{\prime} 58.80^{\prime \prime}$ & Laut Dalam \\
\hline
\end{tabular}

Sampel air laut diambil langsung pada setiap titik koordinat yang telah ditentukan dengan GPS. Pengambilan sampel air laut dilakukan botol polietilen yang diturunkan ke dalam permukaan air laut pada kedalaman \pm 1 $m$ dalam keadaan terbalik (mulut botol berada di bawah). Kemudian mulut botol dibalik dan tunggu sampai terisi penuh $( \pm 250 \mathrm{~mL})$ dan segera ditutup saat masih berada di dalam air laut. Setelah itu dilakukan penambahan $\mathrm{HCl}$ pekat (p.a) sebanyak 1 tetes untuk mencegah logam agar tidak menempel pada dinding wadah, kemudian sampel disimpan dalam cooler box. Sampel air laut yang telah diambil dari perairan Teluk Staring Kabupaten Konawe Selatan, selanjutnya dibawa ke
Laboratorium Analitik Fakultas Matematika dan Ilmu Pengetahuan Alam, Universitas Halu Oleo, Kendari untuk dipreparasi dan dianalisis lebih lanjut.

Sampel air laut 12 stasiun dikocok sampai homogen. Kemudian difilter dengan filter Millipore HA (ukuran pori $0,45 \mu \mathrm{m}$ ) ke dalam botol polietilen yang telah dibersihkan untuk menghilangkan materi organik dalam sampel. Sampel air laut hasil filter dengan filter Millipore HA (ukuran pori $0,45 \mu \mathrm{m}$ ) ditambahkan asam nitrat $\left(\mathrm{HNO}_{3}\right)$ sampai $\mathrm{pH} 2$ untuk dianalisis dengan instrumen SSA dengan metode kurva kalibrasi.

Urutan Analisis data dilakukan mengacu pada gambar di bawah ini. 


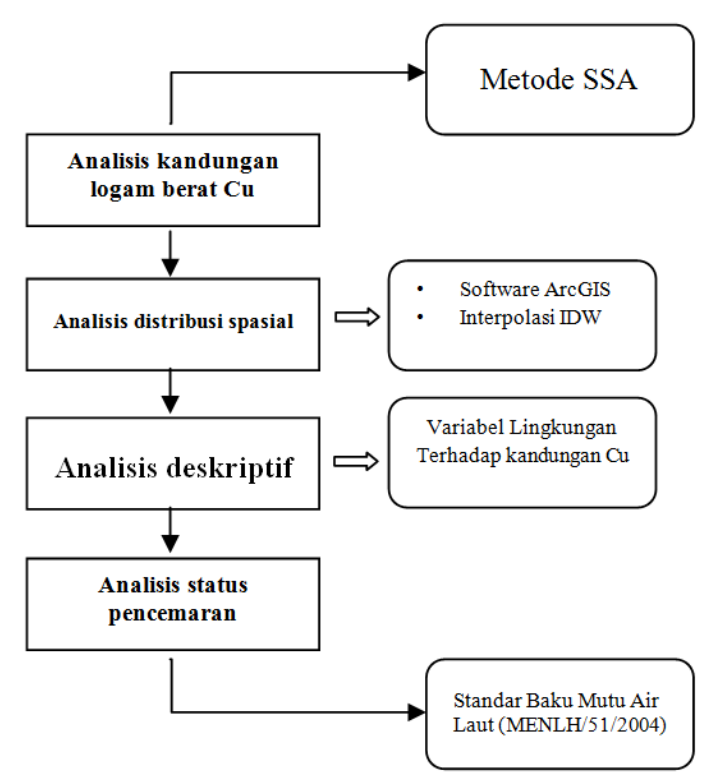

Gambar 2. Bagan Analisis Data

\section{Hasil dan Pembahasan}

Analisis regresi adalah salah satu metode untuk menentukan hubungan sebabakibat antara satu variabel dengan variabel yang lain. Dengan menggunakan metode ini maka nilai konsentrasi logam dalam sampel pada tiap-tiap stasiun dapat diketahui. Hasil pengukuran nilai absorbans dihubungkan dengan nilai larutan standar pada logam tembaga $(\mathrm{Cu})$.

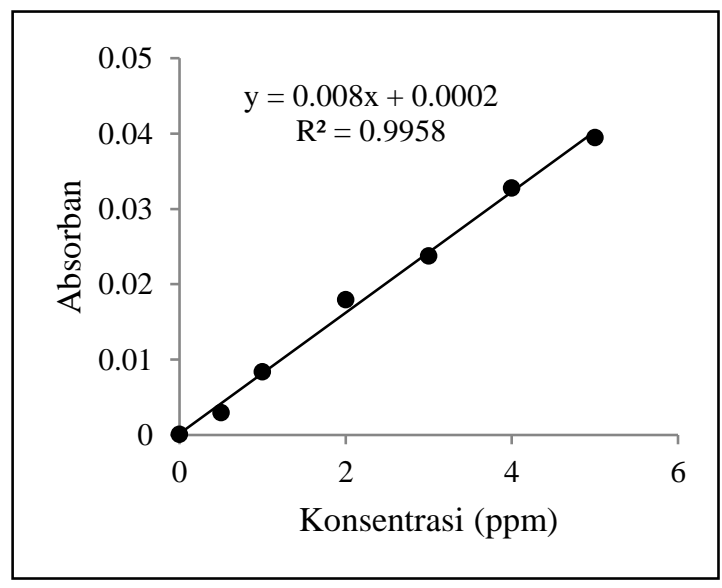

Gambar 3. Kurva Kalibrasi Larutan Standar $\operatorname{Logam} \mathrm{Cu}$

Berdasarkan hasil analisis regresi kurva sesuai pada Gambar 3 yang mana untuk mendapatkan nilai rata-rata sesuai dengan standar, dilakukan sebanyak 2 kali pengukuran deret larutan standar logam $(\mathrm{Cu})$, Setelah melalui perhitungan regresi linier kurva standar, $\mathrm{Y}=\mathrm{bx}+\mathrm{a}$, sehingga diperoleh nilai lereng kurva sebesar 0,008 dengan titik potong kurva adalah 0, maka persamaan regresi kurva pada standar logam Tembaga (Cu) yaitu, $y=0,008 x+0,000$ dengan nilai koefisien $\left(R^{2}\right)=0,995$. Sebagaimana yang dikemukakan oleh Razak (1991), bahwa nilai $r$ yang berada pada kisaran 0,71 - 0,90 memiliki hubungan yang kuat, dan batas deteksi yang diperoleh pada nilai konsentrasi sebesar 6 ppm.

Pada penelitian ini telah diperoleh hasil pada larutan standar dimana nilai absorbansi meningkat seiring dengan peningkatan nilai konsentrasi (ppm).

Validasi metode analisis merupakan suatu tindakan penilaian terhadap parameter tertentu berdasarkan percobaan yang dilakukan di laboratorium untuk membuktikan bahwa parameter tersebut memenuhi persyaratan untuk penggunaannya. Secara umum, validasi metode mencakup penentuan yang berkaitan dengan alat dan metode (Kantasubrata, 2003). Tahapan validasi metode yang dilakukan meliputi uji linearitas dan presisi. Selain itu hasil analisis kadar $\mathrm{Cu}$ dalam Perairan Teluk Staring yang didapat dilakukan uji t untuk mengetahui perbedaan hasil analisis konsentrasi dari kedua metode destruksi basah yang dilakukan. Uji t yang dilakukan pada penelitian ini yaitu uji t tidak berpasangan atau independent sample test (Prihatin et al.,2017).

Uji Linearitas merupakan hasil uji yang berbanding lurus dengan konsentrasi analit dalam sampel pada kisaran tertentu. Liniearitas menggambarkan kemampuan metode analisis memberikan respon proporsional terhadap konsentrasi analit dalam sampel. Liniearitas ditentukan dari nilai koefisien korelasi pada kurva regresi hasil pengukuran larutan standar.

Liniearitas yang dihasilkan dapat dilihat dari harga koefisien korelasi (r2) pada larutan standar Tembaga sebesar 0,995 dimana harga koefisien korelasi ini telah memenuhi syarat yang diperbolehkan menurut Handayani \& Lestari (2012) yaitu > 0,997. Hasil tersebut menunjukkan bahwa alat yang digunakan mempunyai respon yang baik terhadap sampel, sehingga persamaan regresi linear yang diperoleh dapat digunakan untuk menghitung konsentrasi sampel air di perairan Teluk Staring. 


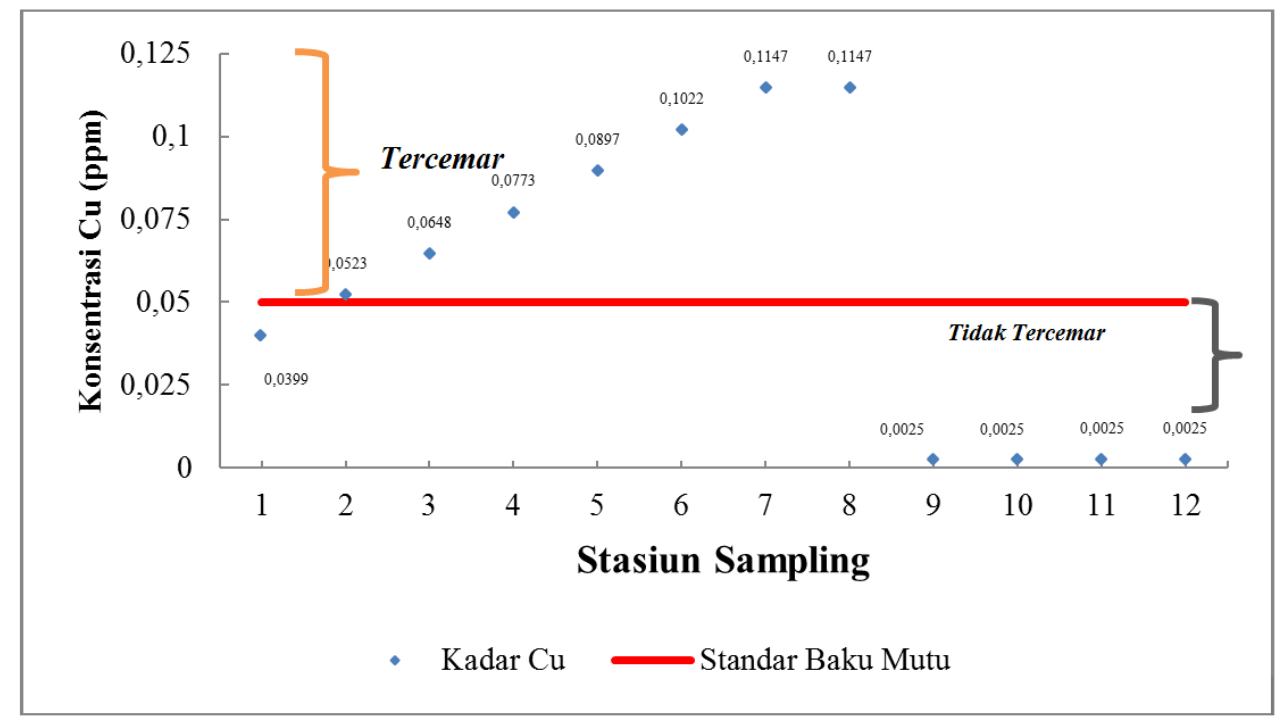

Gambar 4. Konsentrasi Cu di 12 Stasiun perairan Teluk Staring

Persamaan regresi linear yang diperoleh pada kurva kalibrasi selanjutnya digunakan untuk menghitung konsentrasi logam Tembaga (Cu) di 12 stasiun sampel yang akan dianalisis. Pengukuran absorbans sampel 12 stasiun dilakukan sebanyak 2 kali ulangan dengan dua kali faktor pengenceran, nilai konsentrasi $\operatorname{logam} \mathrm{Cu}(\mathrm{Gambar} 4)$.

GIS merupakan sistem informasi kebumian berbasis sistem georafis. Dalam berbagai perencanaan GIS merupakan suatu model alternatif dari kegiatan dan proses dalam lingkungan dimana dapat dilakukan aktivitas pengukuran (measurement), pemetaan (mapping), monitoring (monitoring) dan pemodelan (modeling) (Star dan Etes, 1990).

Interpolasi adalah proses estimasi nilai pada suatu wilayah yang tidak terukur dan mendistribusi data spasial logam berat tembaga (Cu) di 12 stasiun yang telah diteliti di daerah Teluk Staring, sehingga terbentuklah peta atau sebaran nilai pada seluruh wilayah. Teknik dalam metode interpolasi yaitu teknik Inverse Distance Weight (IDW) dan Kriging. Metode IDW dapat dikelompokan dalam estimasi deterministic dimana interpolasi dilakukan berdasarkan perhitungan matematik. Sedangkan metode kriging dapat digolongkan ke dalam estimasi stochastic dimana perhitungan secara statistik dilakukan untuk menghasilkan interpolasi. Metode IDW yaitu teknik yang menunjukan hasil interpolasi yang lebih mirip dengan data sampel yang jaraknya lebih dekat daripada yang lebih jauh. Bobot (weight) akan berubah secara linear sesuai dengan jaraknya dengan data sampel. Lain halnya dengan kriging yaitu interpolasi dengan perhitungan secara statistik, sehingga tidak dapat sesuai apabila digunakan dalam analisis spasial.

Logam berat yang masuk ke dalam lingkungan perairan akan mengalami pengendapan, pengenceran dan disperse, kemungkinan diserap oleh organisme yang hidup di perairan tersebut (Hutagalung, 1991). Gambar 5 berikut merupakan peta penyebaran logam tembaga $\mathrm{Cu}$ pada lokasi penelitian di perairan Teluk Staring.

Pencemaran Logam berat di perairan merupakan salah satu penyebab rusaknya suatu ekosistem perairan baik dari tumbuhan maupun pada biota, tingkat pencemaran tersebut diakibatkan oleh aktivitas manusia yaitu pembuangan limbah industri dan aktivitas pelayaran yang mengandung bahan-bahan kimia. Hal ini terjadi di Perairan Teluk Staring yang memiliki tingkat pencemaran sebesar $80 \%$ kandungan Logam berat Tembaga $(\mathrm{Cu})$ yang melebihi standar Baku Mutu yang di tetapkan oleh KepMen LH, No. 51 Tahun 2004.

Dari Tabel 3 menunjukkan bahwa tingkat pencemaran logam Tembaga $\mathrm{Cu}$ di Perairan Teluk Staring dengan menggunakan perbandingan baku mutu pada perairan pelabuhan dan biota laut menunjukkan bahwa telah terjadi tingkat pencemaran yang sangat luas khusunya di bagian wilayah pesisir Teluk Staring yaitu pada stasiun 1, 2, 3, 4, 5, 6, 7 dan 8 dengan kisaran nilai kadar logam 0,0399$0,1147 \mathrm{ppm}$. 
Tabel 3. Analisis Status Pencemaran

\begin{tabular}{cccc}
\hline & & \multicolumn{2}{c}{ Status Pencemaran } \\
\cline { 3 - 4 } Stasiun & $\begin{array}{c}\text { Kadar Logam Cu } \\
(\mathbf{m g} / \mathbf{l})\end{array}$ & $\begin{array}{c}\text { Perairan Pelabuhan } \\
(\mathbf{0 , 0 5} \mathbf{~ m g / l )}\end{array}$ & $\begin{array}{c}\text { Biota Laut } \\
\mathbf{( 0 , 0 0 8} \mathbf{~ m g / l )})\end{array}$ \\
\hline 1 & & & $\sqrt{ }$ \\
2 & 0,0399 & $\mathrm{X}$ & $\sqrt{ }$ \\
3 & 0,0523 & $\sqrt{ }$ & $\sqrt{ }$ \\
4 & 0,0648 & $\sqrt{ }$ & $\sqrt{ }$ \\
5 & 0,0773 & $\sqrt{ }$ & $\sqrt{ }$ \\
6 & 0,0897 & $\sqrt{ }$ & $\sqrt{ }$ \\
7 & 0,1022 & $\sqrt{ }$ & $\mathrm{X}$ \\
8 & 0,1147 & $\sqrt{ }$ & $\mathrm{X}$ \\
9 & 0,1147 & $\mathrm{X}$ & $\mathrm{X}$ \\
10 & 0,0025 & $\mathrm{X}$ & \\
11 & 0,0025 & $\mathrm{X}$ & $\mathrm{X}$ \\
12 & 0,0025 & & \\
\hline
\end{tabular}

Keterangan: X( Tidak Tercemar); $\sqrt{ }$ (Tercemar)

Tingkat pencemaran logam Tembaga $(\mathrm{Cu})$ di Perairan Teluk Staring pada model Interpolasi dengan menampilkan dua jenis warna (tercemar dan tidak tercemar) yang sangat jelas, bagian Wilayah Pesisir Teluk memiliki tingkat pencemaran yang sangat luas, hal ini diakibatkan oleh aktivitas tambang batu Moramo, pelayaran kapal tongkang dan kapal nelayan yang melewati bagian perairan pesisir Teluk hingga pabrik semen diduga akibat tercemarnya logam berat $\mathrm{Cu}$ pada Stasiun 2, 3, 4, dan 5. Sama halnya pada stasiun 6,7 dan 8 yang ditandai warna Orange juga memiliki tingkat pencemaran yang sangat tinggi, terletak di sekitar daratan Kecamatan Laonti dimana terdapat aktivitas pertanian yang sangat luas dan adanya muara sungai terbesar Laonti yang bermuara ke Teluk Staring. Sehingga di duga bahan-bahan kimia yang mengandung pestisida akibat kegiatan pertanian tersebut menyebabkan pencemaran Logam berat $\mathrm{Cu}$.

Berdasarkan hasil analisis kandungan logam berat Tembaga $(\mathrm{Cu})$ yang terlarut di Perairan Teluk Staring sebanyak 12 stasiun yaitu berkisar antara 0,0025-0,1147 ppm. Bila dibandingkan dengan standar baku mutu yang ditetapkan oleh Kepmen LH No.51 Tahun 2004 dengan nilai $0,05 \mathrm{mg} / \mathrm{l}$, dan $0,008 \mathrm{mg} / \mathrm{l}$. Hal ini menunjukan bahwa nilai kadar Logam Tembaga $(\mathrm{Cu})$ pada Stasiun 2, 3, 4, 5, 6, 7 dan 8 sudah melebihi standar baku mutu yang telah ditetapkan dan ditolerir oleh ekosistem diperairan Teluk Staring.

Kadar logam tertinggi terdapat pada stasiun 6, 7 dan 8 dengan nilai kadar logam berkisar 0,1022 ppm dan 0,1147 ppm. Secara garis besar bahwa di daerah tersebut merupakan aliran sungai terbesar Laonti, yang dimana kegiatan pertanian oleh masyarakat di Kecamatan Laonti sangat banyak, sehingga adanya bahan-bahan kimia seperti pestisida juga berpontesi besar mempengaruhi kadar logam Tembaga $(\mathrm{Cu})$ yang di bawa langsung oleh aliran sungai Laonti ke Laut.

Kadar logam tinggi yang melebihi batas baku mutu air laut juga terdapat pada Stasiun 2, 3, 4, dan 5 yaitu berkisar 0,0523 ppm, 0,0648 ppm, 0,0773 ppm dan 0,0897 ppm. Kondisi ini disebabkan bahwa pada titik-titik tersebut terdapat beberapa industri seperti PLTU, Tambak, Pabrik Semen dan Tambang Batu, yang limbahnya langsung terbuang ke laut melalui sungai yang ada pada daerah tersebut, selain itu, pengaruh limbah rumah tangga dan lintasan kapal nelayan maupun kapal pabrik yang mengakibatkan tumpahan minyak juga menjadi penyebab dari tingginya kadar logam Tembaga $\mathrm{Cu}$ di Teluk Staring. Sedangkan pada stasiun 1, 9, 10, 11 dan 12 memiliki kadar logam di bawah standar baku mutu atau tidak tercemar yaitu berkisar $0,0399 \mathrm{ppm}$ dan $0,0025 \mathrm{ppm}$, hal ini disebabkan karena pada titik-titik ini berada 
di tengah teluk yang dekat dengan laut lepas sangat kecil. sehingga pengaruh dari aktivitas masyarakat

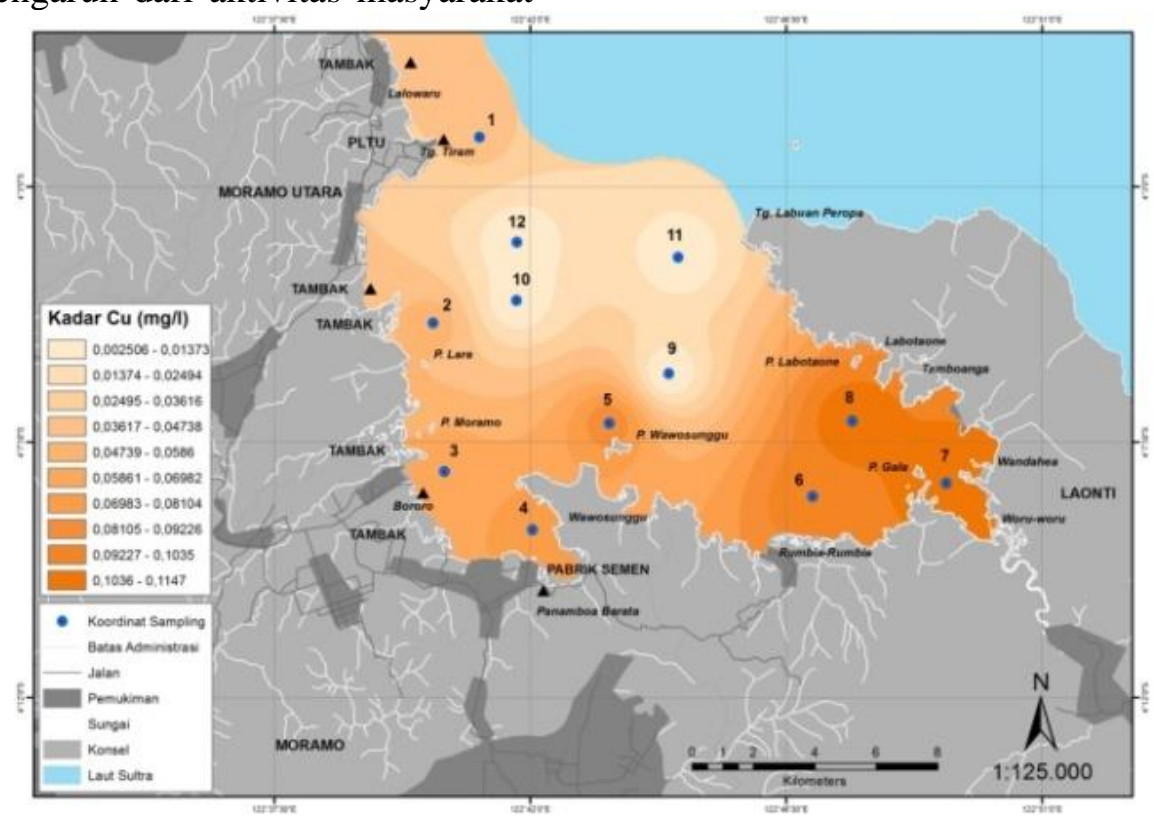

Gambar 5. Sebaran Logam Cu pada 12 Stasiun Setelah Interpolasi

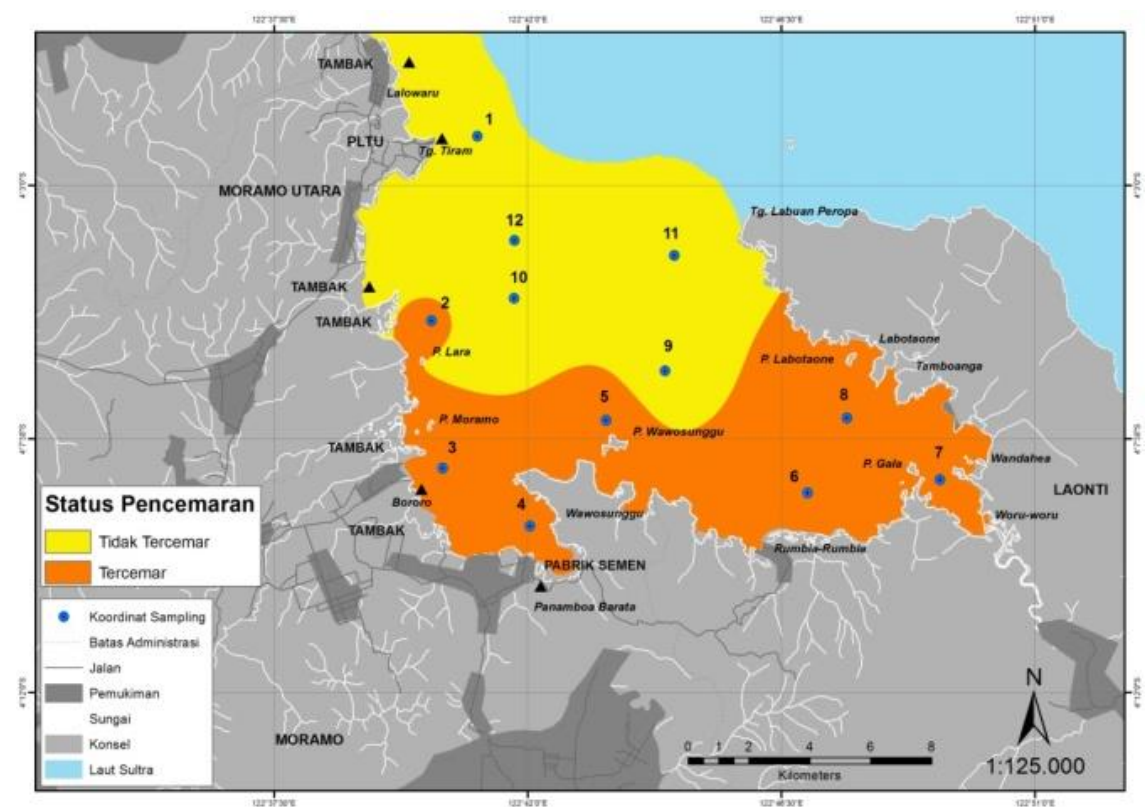

Gambar 6. Sebaran Tingkat Pencemaran Logam Cu pada 12 Stasiun

Berdasarkan data analisis distribusi spasial logam Tembaga $\mathrm{Cu}$ di Perairan Teluk Staring menunjukan bahwa sebagian besar wilayah teluk telah tercemari logam berat $\mathrm{Cu}$ yaitu di Stasiun 2, 3, 4, 5, 6, 7 dan 8 dengan kisaran nilai $0,0523-0,1147 \mathrm{ppm}$. Hal ini disebabkan Tembaga yang masuk ke dalam tatanan lingkungan perairan berasal dari peristiwa-peristiwa alami dan sebagai efek samping dari aktivitas yang dilakukan oleh manusia. Aktivitas manusia seperti buangan limbah industri, galangan kapal dan bermacam-macam aktivitas pelabuhan lainnya yang merupakan salah satu penyebab terjadinya peningkatan kelarutan $\mathrm{Cu}$ dalam badan perairan. Oleh karena itu, wilayah teluk yang tercemar tersebut sangat dekat dengan daerah aliran sungai, sehingga menyebabkan material-material yang berasal dari daratan akibat aktivitas manusia akan terbawa oleh aliran sungai yang bermuara ke laut.

Adapun lokasi yang tidak tercemar yaitu Stasiun 1, 9, 10, 11 dan 12 dengan kisaran nilai 0,0025-0,0399 ppm hal ini 
disebabkan bahwa daerah ini berada ditengah teluk yang dekat dengan laut lepas, sehingga pengaruh langsung yang berasal dari darat sangat kecil. Berdasarkan indeks interpolasi kadar logam berat Tembaga $\mathrm{Cu}$ berada pada stasiun 6, 7 dan 8 dengan kisaran nilai yaitu sebesar 0,1022 dan $0,1147 \mathrm{ppm}$, yang ditandai pada Gambar 6 berwarna Orange Tua, sedangkan indeks interpolasi terendah berada pada Stasiun 1, 9, 10, 11, dan 12 dengan kisaran kadar logam $\mathrm{Cu}$ yaitu sebesar 0,0399 dan 0,0025 ppm, ditandai dengan degradasi warna Putih dan Orange Muda.

Sesuai pada Gambar 7 dengan menggunakan model interpolasi yang menampilkan dua jenis warna (tercemar dan tidak tercemar), menunjukan bahwa pada daerah stasiun yang berwarna Orange sudah tercemar dan memiliki kadar logam $\mathrm{Cu}$ melebihi standar baku mutu sesuai Kepmen LH No.51 Tahun 2004. Pada stasiun 2, 3, 4 dan 5 dengan kisaran nilai 0,0532-0,0897 ppm menunjukkan tingkat pencemaran sedang, berbeda dengan stasiun 6,7 dan 8 yang memiliki kisaran nilai 0,1022-0,1147 ppm dengan tingkat pencemaran yang sangat tinggi. Hal ini diakibatkan oleh aktivitas tambang batu Moramo, pelayaran kapal tongkang dan kapal nelayan yang melewati bagian perairan pesisir Teluk hingga pabrik semen diduga akibat tercemarnya logam berat $\mathrm{Cu}$. Selain itu, terdapat sungai terbesar Laonti yang bermuara ke Teluk Staring dimana terdapat aktivitas pertanian yang sangat luas di daratan Kecamatan Laonti. Sehingga di duga bahan-bahan kimia yang mengandung pestisida akibat kegiatan pertanian tersebut menyebabkan pencemaran Logam berat $\mathrm{Cu}$. Sedangkan bagian stasiun yang berwarna Kuning yaitu stasiun 1, 9, 10,11 dan 12 masih memiliki nilai di bawah standar batas toleransi yakni berkisar 0,0025 ppm sampai 0,0399 ppm dan belum dikatakan tercemar.

\section{Simpulan}

Berdasarkan hasil penelitian dan pembahasan yang telah diuraikan, maka dapat disimpulkan sebagai berikut:

1. Logam berat Tembaga $(\mathrm{Cu})$ yang dianalisis menggunakan Atomic Absorption Spectrophotometer (AAS) memiliki nilai rata-rata $0,055 \mathrm{ppm}$, dengan nilai kadar logam tertinggi $0,1147 \mathrm{ppm}$ dan nilai terendah $0,0025 \mathrm{ppm}$.
2. Pada peta penyebaran distribusi logam berat Tembaga $(\mathrm{Cu})$ yang menggunakan metode interpolsi IDW memiliki tingkat pencemaran yang luas dan tinggi terdapat pada Stasiun 2, 3, 4, 5, 6 dan 7 dengan warna degradasi yang tebal.

3. Status pencemaran logam berat $(\mathrm{Cu})$ melebihi standar baku mutu yang ditetapkan oleh Kepmen LH No.51 Tahun 2004 yang terdapat pada stasiun 2, 3, 4, 5, 6,7 dan 8 dengan kadar logam 0,0532$0,1147 \mathrm{ppm}$.

\section{Daftar Pustaka}

Anazawa, et al. 2004. Heavy-Metal Distribution in River Waters and Sediments Around a"Firefly Village", Shihoku, Japan: Application of Multivariate Analysis. Analytical Sciences, Januari Vol. 20: 79-84.

Armid. 2015. Distribusi Spasial Logam Berat $\mathrm{Pb}$ pada Perairan Teluk Kendari, Sulawesi Tenggara. Biowallacea. 2(2): $220-228$.

Baird, 1995. Environmental Chemistry. W. H. Freeman and Company. New York. 484 hlm.

Bryan, G.W. 1984. Heavy Metal Contamination in The Sea. Marine Pollution

Bulletin. London Academica Press. London.

Child, C., 2004, Interpolating Surface in ArcGIS Spatial Analyst: New York, ESRI Education Service.

Clark, J.J., Hindelang. T.J., (1989) : Capital budgeting: planning and control of capital expenditures. New Jersey: Prentice-Hall.

Dahuri, R. 2003. Keanekaragaman Hayati Laut ; Aset Pembangunan

Berkelanjutan. PT Gramedia Pustaka Utama. Jakarta.

Darmono. 1995. Logam dalam Sistem Biologi Makhluk Hidup. Penerbit UI Press.

Jakarta.

Darmono. 2001, lingkungan hidup dan pencemaran, hubungannya dengan toksikologi senyawa logam. Jakarta : UI press

Darmono. 2001. Logam dalam Sistem Biologi Makhluk Hidup. Universitas Indonesia pers. Jakarta.

Duffus, J.J. 1980. Environmental Toxicology. London: Edward Arnold (Publishers) Ltd. 
Effendi, H. 2003. Telaah Kualitas Air bagi Pengelolaan Sumberdaya dan Lingkungan Perairan. Cetakan Kelima. Kanisius. Yogjakarta.

Eryati, R. 2008. Akumulasi Logam Berat dan Pengaruhnya Terhadap Morfologi Jaringan Lunak Karang di Perairan Tanjung Jumlai, Panajam Paser Utara, Kalimantan timur. Tesis. Program pasca Sarjana IPB. Bogor. 136 hal.

Fardiaz, S. 1992. Polusi Air dan Udara. Penerbit Kanisius. Yogyakarta

Gibs, R.J. 1973.Mechanisms Of trace Metal Transport In Rivers, Since 180, 71-73

G.W. Bryan, in: A.P.M. Lockwood (Ed). Some Aspects of Heavy Metal Tolerance in Aquatic Organism. Effects of pollutants on Aquatic Organisms. Cambridge University Press, Cambridge, 1976, 431.

G.W. Bryan, In: A. P. M. Lockwood (Ed.), Effects of Pollutants on Aquatic Organisms, Cambridge University Press, Cambridge, 1976.

Hamuna, et al., 2018. Kajian Kualitas Air Laut dan Indeks Pencemaran Berdasarkan Parameter Fisika-Kimia Di Perairan Distrik Depapre, Jayapura. Jurnal Ilmu Lingkungan.

Handayani, H.N. \& N. O. Lestari.2012.Isolasi Metamfetamina di Dalam Urin dengan Menggunakan Solid Phase Extraction (SPE). Tugas Akhir. Bandung: Politeknik Negeri Bandung

Horsfall. Jr. M. and Spiff, A.L., 2002. Distribution and Partitioning of Trace Metals in Sediment of The Lower Reaches of The New Calabar River, Port Harcourt, Nigeria. J.Environmental Monitoring and Assessment. 78: 309326

Hutagalung HP. 1984. Logam Berat dalam Lingkungan Laut. Pewarta Oceana IX

No.1 Tahun 1984.

Hutagalung HP. 1991. Pencemaran Laut oleh Logam Berat. Dalam Status Pencemaran Laut di Indonesia dan Teknik Pemantauannya. P30-LIPI. Jakarta.

Hutagalung HP. 1984. Logam berat dalam lingkungan laut. Pewarta Oseana. Vol

IX. No.1. LON LIPI. Jakarta

Keputusan Menteri Lingkungan Hidup Nomor :51/MENLH/2004, tentang penetapan baku mutu air laut dalam himpunan peraturan di bidang lingkungan hidup. Jakarta.

Kantasubrata, J. 2003. Dasar Ketidakpastian Pengukuran. Pengantar ISO Guide

Uncertainty of Measurement, Serpong, 22-23.

Laws EA. 1993. Aquatic Pollution an Introductory Text. 2nd Edition. An Interscience Publication John Willey and Sons, Inc. New York. USA.

Laws, E. A. 1993. Aquatic Pollution an Introductory Text. Third Edition. Canada

(US): J Wiley. $611 \mathrm{hlm}$.

Morel, F. M. M., and Hering, J. G., 1993, Principles and Application of Aquatic Chemistry, John Wiley and Sons, New York.

M. Waldichuck, in: Verberg \& Venberg (Ed.) Some Biological Concern in Heavy Metals Pollution. Pollution and Psysiology of Marine Organism. Academic Press, London, 1974, 231.

M. Waldichuck. In: Verberg \& Venberg (Eds.), Pollution and Physiology of Marine Organism, Academic Press, London, 1974.

Moore, J. W. \& S. Ramamoorthy. 1984. Heavy Metals in Neutral Water. Springer

Verlag. New York.

Mukhtasor. 2007. Pencemaran pesisir dan laut. Jakarta. PT Pradnya Paramita.

Nontji, A., 2002. Laut Nusantara. Penerbit Djambatan. Jakarta: 59-67.

Nontji A. 2007. Laut Nusantara (edisi revisi). Djambatan. Jakarta.

Nontji, A. 1993. Laut Nusantara. Cetakan Kedua. Djambatan. Jakarta.

Novotny V \& Olem H. 1994. Water Quality; Prevention, Identification, and

Management of Diffuse Pollution. Van Nostrand reinhold. New York.

Nybakken, W.J., 1988. Biologi Laut. Suatu Pendekatan Ekologis. Gramedia, Jakarta: 459 hal.

Nybakken JW. 1992. Biologi Laut Suatu Pendekatan Ekologi. PT Gramedia. Jakarta.

Nybakken JW. 1992. Biologi Laut, Suatu Pendekatan Ekologis (dari Marine Biology: An Ecological Approach. Penerjemah EH. Muhammad et al (edisi pertama).

PT. Gramedia. Jakarta. 
Palar, H. (1994). Pencemaran dan Toksikologi Logam Berat. Penerbit Rineka

Cipta. Jakarta.

Palar, H. 2004. Pencemaran dan Toksikologi Logam Berat. Penerbit Rineka Cipta. Jakarta.

Palar, H. 2008. Pencemaran dan Toksikologi Logam Berat. Jakarta: PT. Rineka Cipta.

Peraturan Pemerintah Republik Indonesia Nomor 19 Tahun 1999 Tentang Pengendalian Pencemaran Dan/Atau Perusakan Laut.

Prihatin, A. W., A.T. Prasetya, \& W. Sumarni. 2017. Validasi Metode Analisis Mn dalam Sungai Kaligarang dengan ICP-OES dan GFAAS. Indonesian Journal of Chemical Science, 6 (1): 1-8

Rahman, A dan Akhmad M. 2016. Kesesuaian Pemanfaatan Perairan bagi Pengembangan Perikanan Budidaya di Kawasan Teluk Staring Konawe Selatan. Jurnal Bisnis Perikanan. 3 (1): 31-38.

Razak, A. 1991.Statistik Bidang Pendidikan Fakultas Keguruan dan Ilmu Pendidikan Universitas Riau. Pekanbaru.

Sanusi, H.S, 2006. Kimia Laut Proses Fisik Kimia dan Interaksinya dengan

Lingkungan. Departemen Ilmu dan Teknologi kelautan, Fakultas Perikanan dan Ilmu Kelautan. Institut Pertanian Bogor.

Sanusi HS. 2006. Kimia Laut, Proses Fisik Kimia dan Interaksinya dengan Lingkungan. Bogor (ID): IPB Press.

Sarjono, A. 2009. Analisis Kandungan Logam Berat $\mathrm{Hg}, \mathrm{Pb}$ dan $\mathrm{Cu}$ dalam Air

dan Jaringan Tubuh Kerang Hijau (Perna viridis) di Kamal Muara. Jakarta Utara, Departemen Managemen Sumberdaya Perairan. Fakultas Perikanan dan Ilmu Kelautan IPB , Bogor.

Supardi, I. 1984. Lingkungan Hidup dan Kelestariannya. Tropical Marine Pollition. MSC. Report. Dept. Upon Tyne New Castel Upun Tyne, U.K. Pustaka. Jakarta.

Star, J. Estes, J. 1990. Geographic Information Systems: an Introduction. New Jersey: Prentice Hall.

Vries, et al (2002) Agricultural, Hydrology and Water Quality. The Netherlands National Institut of Public Health and Environment. Netherlands.
Widowati, W., Sastiono, A., Jusuf, R. 2008. Efek Toksik Logam. Penerbit ANDI, Yogyakarta. 